International Journal of Managing Information Technology (IJMIT) Vol.7, No.1, February 2015

\title{
RELATIONSHIP BETWEEN ORGANIZATIONAL FACTORS, TECHNOLOGICAL FACTORS AND ENTERPRISE RESOURCE PLANNING SYSTEM IMPLEMENTATION
}

\author{
Suha Afaneh $^{1}$, Issam AlHadid ${ }^{2}$ and Heba AlMalahmeh ${ }^{3}$ \\ ${ }^{1}$ Department of Computer Science, Isra University, Amman, Jordan \\ ${ }^{2}$ Department of Computer Information Systems, Isra University, Amman, Jordan \\ ${ }^{3}$ Department of Management Information Systems, Isra University, Amman, Jordan
}

\begin{abstract}
There are three stages of Enterprise Resource planning System (ERP) Implementation; which are preimplementation, mid-implementation and post-implementation. In pre-implementation stage the pervious researchers found that it fail in Organizational and Technological factors. Therefore, this research studies the Technological Factors availability and the Organizational Factor readiness at Greater Amman Municipality (GAM) Case study. The statistical results showed that there are availability of the Organizational factor (Organizational Objectives and Services, Organization culture, and Business process) for success of ERP system, and indicate the technological infrastructure is available og GAM.
\end{abstract}

\section{KEYWORDS}

Enterprise Resource Planning, C Critical Success Factors , $\quad$ ERP Implementation.

\section{INTRODUCTION}

Over the last few decades, there has been an ever increasing interest in the area of the Enterprise Resource Planning System (ERP); because this ERP system typically attempts to cover all basic functions of business, regardless of the organizations business or charter. Business, Non- profit Organization, Non Governmental Organization, Governments and other large entities utilize ERP system[1].

During recent years, public organizations have invested considerable resources in the implementation of ERP systems, even using solutions initially targeted for manufacturing companies. The interest generated by the ERP phenomenon in the Public-sector still growing and the particularities of this sector make specific studies necessary[2]. It has been observed that the ERP system can be failure either in the design or implementation stage, the success or failure of the ERP system is subjected to many reasons, and the implementation of the ERP system in an organization can be very complex. It can be considered as a high-risk project since it almost affects the whole performance and functioning of the organization, thus it should be managed and planned properly. It is difficult and costly to implement the ERP system due to the tremendous needed time and resources.

The importance of this study that it discusses how the Organizational and Technological Factors do affect the ERP system implementation in the Jordanian organizations, it has recently used in 
International Journal of Managing Information Technology (IJMIT) Vol.7, No.1, February 2015

the beginning, and the researchers are trying to figure out the factors that could affect the proper use of it. This study aims to enrich other studies about the ERP system, specially that it has been newly used in the Jordanian public service organizations. It should be mentioned here that Jordan is small country with few resources, and greatly influenced by the circumstances of the global economy. Besides, GAM represents the Jordanian environment, it is an independent institution that uses its own resources, and it has been suffering from disability of budget, yet, GAM has recently implemented the ERP system, so this study is conducted to assess the readiness of GAM's Organizational and Technological resources for such a huge project to ensure that the system is being implemented in a manner that achieves the best of it, and does not constitute a burden on the organization.

The GAM is going now through the early (pre-implementation) stage of the system, which make it possible for the researchers to monitor and observe the ability of the Organizational and Technological Factors to take responsibility for implementing the system, and that will consequently help to avoid the mistakes that could lead to system failure. In addition to all above, this study can be considered as a foundation to other future studies regarding the ERP system implementation in governmental institutions and ministries in Jordan.

\subsection{The Operational Definitions}

ERP System: An ERP system is an integrated information system which helps organization to make integrate between functions and jobs to achieve organizational goals.

Critical Success Factors (CSFs): Elements related to the adoption and installation of ERP that are thought to lead to successful implementation.

ERP Implementation: a stage on ERP System life cycle which helps to install, design, configure, test and prepare software to use.

Organizational Objectives: An objective is something organization wants to achieve. Organization wants to perform well in business examination; organization wants to earn money to sustain your livelihood; organization wants to be a good citizen; organization wants to help the poor and needy people. What are these? These may be different objectives that organization wants to achieve in it life. In the similar way every organization has several objectives, which it wants to achieve. What are those objectives?[3].

Organization Culture: Is a mixture of cultures and experiences of employees and the laws of the internal organization.

Business Process: is a network of connected activities with well defined boundaries and precedence relationships that utilized resources to transform inputs and outputs with the purpose of satisfying customer requirements.

Network and Communication Technology: A network simply, is a collection of hardware components and computers interconnected by communication channels that allow sharing of resources and where at least one process in one device is able to information send/receive data to/from at least one process residing in a remote device, then the two devices are said to be in a network. Simply, more than one computer interconnected through a communication media for information interchange is called a computer network.

Technological Infrastructure: The organizational unit of the firm that has the responsibility for managing information resources. 
International Journal of Managing Information Technology (IJMIT) Vol.7, No.1, February 2015

\section{RELATED WORKS}

In Zhang et al [4] explained that increasing the exchange of information and communication between upstream and downstream department in the flow manufacturing enterprises are now crucial to expedite the flow, increase value, reduce flow cost and enhance overall response capability and competitiveness. Hence, they demonstrate that the proposed ERP system is the solution by enhancing efficiently at a low cost and increasing overall performance. According to Garg [5] the Enterprise Resource Planning (ERP) systems have gained popularity among many organizations that seek to increase their efficiency and productivity as well as to streamline their operations. The ERP system was designed as a platform for greater innovation, enabling companies to adopt real time automation, and knowing that the processes could be tightly integrated so as to operate at full capacity. The cost, complexity, and implementation complications of an ERP system imply that organizations must seriously consider the planning and selection process. However costly the planning process may be, making the wrong choice could be far more expensive. Understanding the risks and finding ways to mitigate them is a necessary part of the process. Despite the challenges, legacy modernization is crucial for organizations spending too much to maintain the business value of their outdated information systems. The issue addressed in the study In [6] which is written by William, he focused on the factors that are critical to ERP implementation success. The expert panel was comprised of executives from organizations who had participated in and were experienced with ERP implementation projects. Specifically, the expert panel was assembled to review a list of ERP implementation CSFs that were developed by the researcher. The expert panel was asked to add additional critical ERP success factors to the list if necessary, and then rank them in order of importance. Almashaqba found in [7] the critical factors affecting ERP System implementation success in Jordanian business organizations such as Organization Factor, since it is used newly beginning and researcher trying to find out the reasons behind the factors which affect the proper use of it. Since ERP System used newly in Jordan business organizations so the study trying to enrich the studies in ERP implementation. According to Shah et al [8] the researchers select 24 factors collected from the various past research studies. The research included 24 factors to be studied for its ranking and contribution in ERP implementation success. In the pilot survey 24 factors were included in the questionnaire, however only 14 factors were found having Cronbach Alpha value equal or greater than 0.70 . Therefore these 14 factors were included in the final survey. The ranking of the factors considered was found a bit different from the past research findings. The top most five factors found to be critical were professional manpower, project scope definition, and business process re-engineering, top management support and change management. The research found professional manpower as the top most critical factor whereas different past studies showed top management as a top most factor. It is speculated that the professional manpower in countries like Pakistan may have less awareness and practical exposure of ERP system implementation. So the organizations may not ignore this factor during the implementation of ERP. The most famous framework to define implementation success was developed by DeLone and McLean's[9]. The authors found that there is no 'one measure' for an information system success and thus they identified six different factors: system quality, information quality, use, user satisfaction, individual impact and organizational impact. Based on both studies, the proposed success framework is developed to address different dimensions (financial, technical, human) at different points of time (early operational metrics and long term business results)[9].According to Yusuf et al.[10] the issues and challenges of ERP implementations can be summarized into three areas: 1) people, 2) technology, and 3) business (organization). ERP implementation Accordingly, CSFs should be grouped and viewed within these areas. A further understanding of the critical success factors (CSFs) that leads to successful ERP implementation. 
This study is the first for discuss the critical success factor which impact in implementing ERP System in public sector in Jordan. The researcher found a lot of studies on the implementation of the system in the private sector, commercial and industrial sectors inside \& outside Jordan, but she did not find any Studies on the implementation of this system in the public sector in Jordan.

\section{THE MODEL}

According to previous studies that are related to the subject of the research, the researchers suggested the study model by choosing the common factors among these studies, that demonstrate the Organizational factors and Technological factors that affect the application of the ERP system, and join them in accordance with the Jordanian environment and the objective of the research to build the model, which is described in Chapter three. Figure (1) shows the research model, and it has two dimensions: (1) Dependent dimension (Variable) Success of ERP System Implementation. (2) Independent dimension (Variables) which are: Organizational factors and Technological factors [7] , [11], [12], [13], [14], [15],[16].

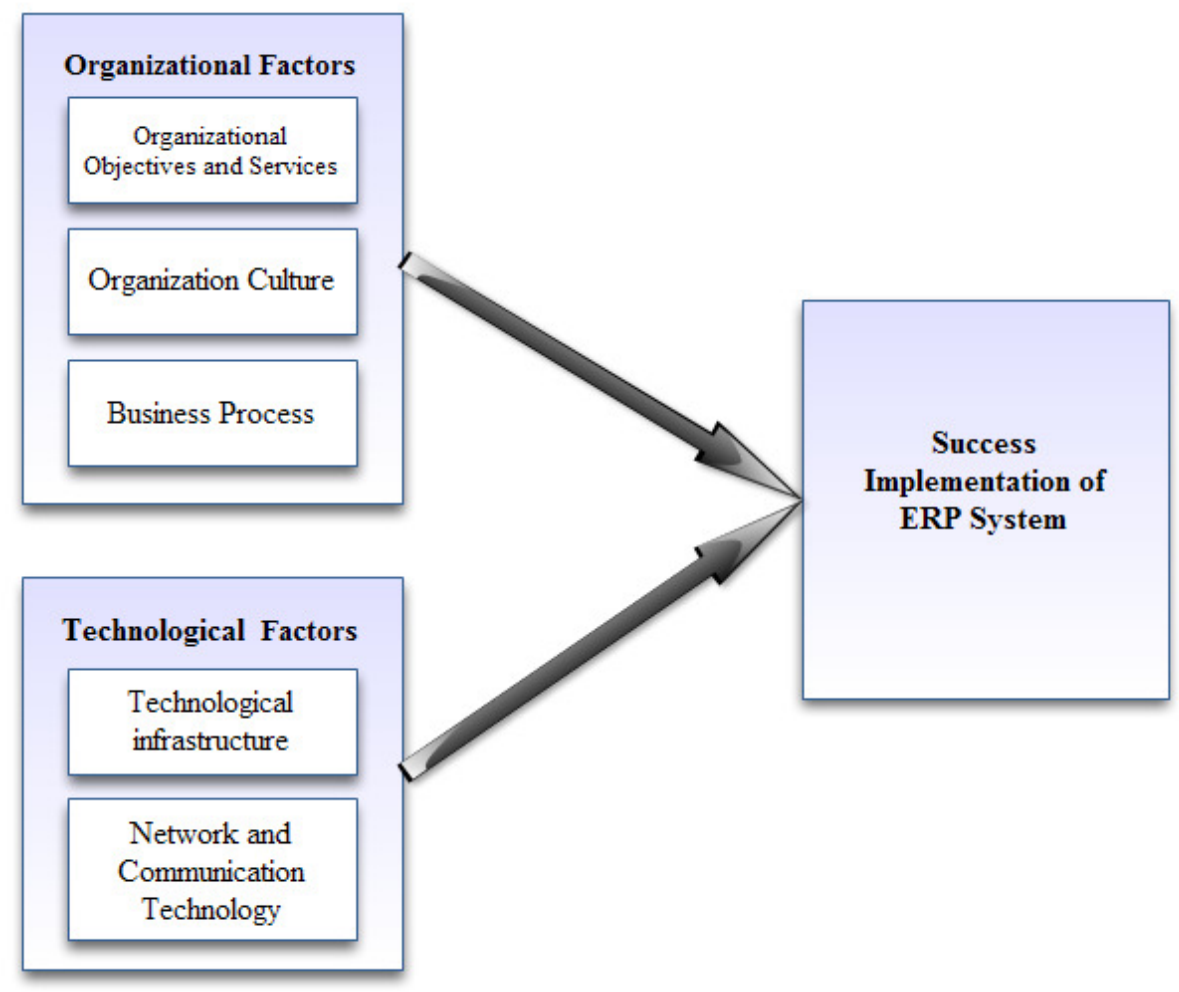

\subsection{The Hypotheses}

Figure 1. The Model

(H1): There Is Significant Correlation between Organizational Factors and ERP system Implementation.

(H1:a) - There is significant Correlation between Organization Objectives and Services and ERP System Implementation.

(H1:b) - There is significant Correlation between Organizational Culture and ERP System Implementation.

(H1:c) - There is significant Correlation between Business Process and ERP System Implementation. 
International Journal of Managing Information Technology (IJMIT) Vol.7, No.1, February 2015

(H2): There Is Significant Correlation between Technological Factors and ERP System Implementation.

(H2:a) - There is significant Correlation between Technological Infrastructure and ERP System Implementation.

$(\mathrm{H} 2: \mathrm{b})$ - There is significant Correlation between Network and Communication Technology and ERP Implementation.

\subsection{The Methodology}

The methodology of this research is based on deductive and quantitative method, thus, a questionnaire is designed to measure the impact of the independent and dependent Organizational and Technological Factors on GAM.

\subsection{The Population and Sample}

The population of the paper consists of the all employees in Greater Amman Municipality $(\mathrm{GAM}) /$ main branch, which is estimated around 2000 employees, the sample size of this population to achieve an acceptable size for analysis is 322 according to [14]. (600) questionnaires were randomly distributed to the working staff in the GAM /main branch building, (400) of them were valid for analysis. Each item in the questionnaire was divided into 5-points according to Likert-type scale[17], and was determined in five levels as the follows: strongly agree given (5) degrees, agree given (4) degrees, neutral given (3) degrees, disagree given (2) degrees, and strongly disagree given (1) one degree. In addition, to use judge scale for the responses, which divided to (high, medium, low), depending on questionnaire four classes (11.99), (2-2.99), (3-3.99) and (4-5). By dividing judge scale classes on the five alternatives (strongly agree, agree, neutral, disagree, and strongly disagree (like the following calculation method) $\quad 1.33=3 \div(1-5)$ As the following in this research the level of significance of the measures was distributed according to table(1).

Table1: Measures Significance Levels

\begin{tabular}{|l|l|}
\hline Likert Scale Levels & Range \\
\hline Strongly Disagree & $1 \_1.80$ \\
\hline Disagree & $1.81 \_2.61$ \\
\hline Neutral & $2.62 \_3.42$ \\
\hline Agree & $3.43 \_4.23$ \\
\hline Strongly Agree & $4.24 \_5$ \\
\hline
\end{tabular}

The level of the significance was used to analyze and study the arithmetic Mean for the sample, whether it is agree or disagree for each question. So if the Mean from 1 to 2.61 degree that means disagree, or the range between 2.62 to 3.42 degree it neutral and if Mean between 3.43 to 5 degree that means agree[17].

\subsection{The Statistical Analysis}

The statistical analysis that is used the following statistical ways by using Statistical Package for the Social Sciences (SPSS) program version (12) to analyze every item in the questionnaire:

-Means and Standard deviation: to examine the hypothesis, and to identify the relative importance .

-Cronbach's Alpha: to verify the reliability of the used questionnaire, in this research, Cronbach's Alpha values ranged between $(0.75-0.89)$ 
International Journal of Managing Information Technology (IJMIT) Vol.7, No.1, February 2015

- Correlation: is a term that refers to the strength of a relationship between two variables. A strong, or high, correlation means that two or more variables have a strong relationship with each other while a weak, or low, correlation means that the variables are hardly related. Correlation coefficients can range from -1.00 to +1.00 . The value of -1.00 represents a perfect negative correlation while a value of +1.00 represents a perfect positive correlation. A value of (0.00) means that there is no relationship between the variables being tested. (www. sociology.about.com). In this study the researcher used Pearson correlation test to find a correlation between the dependent and independent variables[17]

In this research Correlation used to:

- To check the relation between the Organizational Factors and ERP System Implementation.

- to check the relation between the Technological Factors and ERP System Implementation

As for the questionnaire, the researcher calculated Cronbach's Alpha for all the areas to test the reliability for each area, Cronbach's Alpha values ranged between (0.75 - 0.89).

Table 2: Cronbach's Alpha for the research fields

\begin{tabular}{|l|l|l|}
\hline Field number & Field & Value of $(\boldsymbol{\alpha})$ \\
\hline 1 & Organizational factors & 0.86 \\
\hline 2 & Technological factors & 0.89 \\
\hline & Total & 0.875 \\
\hline
\end{tabular}

As shown in table (2) the total Cronbach's alpha for the research fields was (0.84) which leads to the stability of the results for this research, the highest Cronbach's alpha was for the Technological factors (0.89). All the values above are more than $(0.6)$ which is the minimum acceptable value.

\section{RESUlTS AND ANALYSIS}

The Results after applying the required Statistical Analysis are reviewed by describing the demographic characteristics of the paper sample as shown in table (3), after that the hypothesis testing results are reviewed below.

Table 3: Demographic characteristics for the research sample

\begin{tabular}{|l|l|l|}
\hline \multirow{2}{*}{ Variable } & Sample & Frequency \\
\cline { 2 - 3 } & Percentage \\
\hline Sex & 57.2 & 229 \\
\hline Male & 48.8 & 171 \\
\hline Female & 100.0 & 400 \\
\hline Total & \multicolumn{2}{|l|}{ Age } \\
\hline \multicolumn{3}{|l|}{} \\
\hline 25 years old or less & $21.9 \quad 87$ \\
\hline 25- less than 35 years & 44.6 & 178 \\
\hline 35- less than 45 & 23.4 & 92 \\
\hline 45 years or more & 10.1 & 43 \\
\hline Total & 100.0 & 400 \\
\hline
\end{tabular}


International Journal of Managing Information Technology (IJMIT) Vol.7, No.1, February 2015

\begin{tabular}{|l|l|l|}
\hline \multicolumn{3}{|c|}{ Education Level } \\
\hline Diploma & 22.5 & 90 \\
\hline B.C. & 64.9 & 259 \\
\hline M.S. & 12.6 & 51 \\
\hline Total & 100.0 & 400 \\
\hline \multicolumn{2}{|c|}{ Occupation } \\
\hline Top Level Management & 8.6 & 34 \\
\hline Middle Management & 48.6 & 194 \\
\hline Operation Management & 42.8 & 172 \\
\hline Total & 100.0 & 400 \\
\hline \multicolumn{2}{|l|}{ Years of being in service } \\
\hline Less than one - 5 years & 33.3 & 133 \\
\hline 5-less than 10 years & 29.1 & 117 \\
\hline 12-less than 15 years & 26.3 & 105 \\
\hline 15 years or more & 11.3 & 45 \\
\hline Total & 100 & 400 \\
\hline
\end{tabular}

To analyze the data and examine hypotheses, descriptive statistics for each field calculated, in addition to use multiple correlations. Means and Standard deviation calculated for each field in the independent factors and table (4), figures (2) and (3) shows the results.

Table 4: Descriptive Statistics for the Independent Factors

\begin{tabular}{|l|l|l|}
\hline Factors & \multicolumn{2}{|l|}{ Descriptive } \\
\hline & Mean & Standard Deviation \\
\hline 1. Organizational Factors & 3.92 & 0.523 \\
\hline 1.1 Organization objectives and service & 3.87 & 0.554 \\
\hline 1.2 Organizational Culture & 3.94 & 0.538 \\
\hline 1.3 Business Process & 3.96 & 0.506 \\
\hline 2. Technological Factors & 4.14 & 0.503 \\
\hline 2.1 Technological Infrastructure & 4.107 & 0.502 \\
\hline 2.2 Network Communication Technology & 4.18 & 0.505 \\
\hline
\end{tabular}

The table (4) shows descriptive statistics for the independent factors, first the Organizational Factors where the Mean is (3.92) and the Standard deviation around (0.52). The highest Mean for the sub- factors from the Organization Factors is for Business Process which around (3.96) with the lowest Standard deviation (0.506). 
International Journal of Managing Information Technology (IJMIT) Vol.7, No.1, February 2015

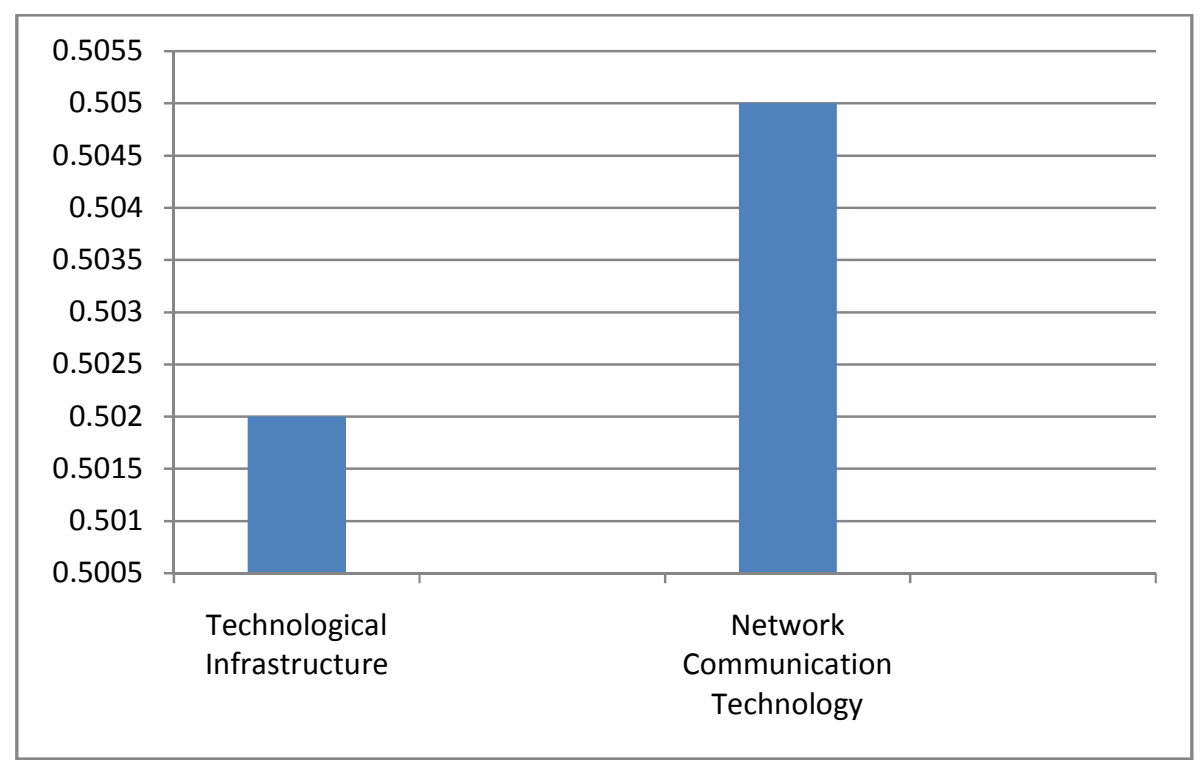

Figure 2. The Mean of Organization Factors

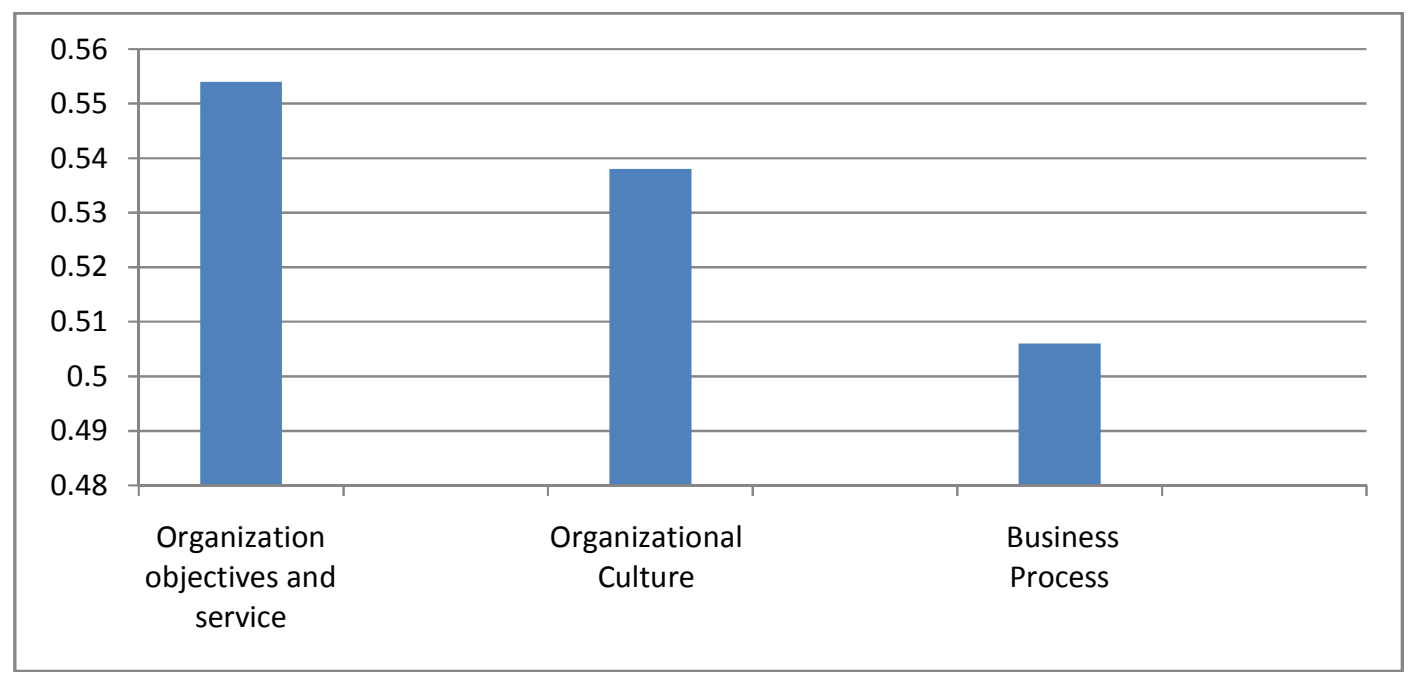

Figure 3. The Mean of Technological Factors

Then, the Technological Factors with two sub-factors: Network communication technology from had the highest Mean (4.18) with a Standard deviation (0.505) and Technological infrastructure with Mean (4.107), Standard deviation (0.502). Table (5) shows the level of significance for main factors which identified by using the arithmetic Mean.

Table 5: Total mean for independent factors

\begin{tabular}{|l|l|l|}
\hline Factors & Mean & Significance level \\
\hline 1. Organizational Factors & 3.92 & Agree \\
\hline 2. Technological factors & 4.14 & Agree \\
\hline
\end{tabular}


International Journal of Managing Information Technology (IJMIT) Vol.7, No.1, February 2015

For testing the hypotheses the researchers tries to answer two questions:

First: Is there a relationship between ERP System and the independent factors of CSFs?

Second: the availability (degree of readiness) of the Organization and Technology Factors for ERP System implementation in GAM?

\subsection{First hypothesis}

(H1): There Is a Significant correlation between Organizational Factors and ERP system Implementation in Greater Amman Municipality.

To examining this Hypothesis the researcher first: calculates Means, Standard deviation and Factor analysis (loading) for each item for the Organizational Factors in GAM. Second calculates Pearson Correlation. Tables from (6) to (11) show the results.

(H1:a) - There is significant correlation between Organization Objectives and Services and ERP system implementation.

To testing this sub-hypothesis the researcher calculate the Mean, Standard deviation and Factor analysis (loading) for all items (from 1 to 10) and calculate the Correlation between group (1) which includes the items from (1 to 7) for Organization Objectives and Services, and group (2) which has the items (from 8 to 10 ) for ERP system.

Table 6: Descriptive Statistics and loading for the Organization objectives and services

\begin{tabular}{|c|c|c|c|}
\hline Section & Mean & Std & Loading \\
\hline \multicolumn{4}{|l|}{ Group 1} \\
\hline 1. The objectives in our organization are obvious for managers & 3.94 & .792 & .680 \\
\hline 2.The objectives in our organization are obvious for employees. & 3.91 & .891 & .743 \\
\hline 3. The procedures are clear for managers. & 4.01 & .811 & .733 \\
\hline 4.The procedures are clear for employees. & 3.93 & .859 & .648 \\
\hline $\begin{array}{l}\text { 5. The daily operations and plans are understood by the } \\
\text { employees. }\end{array}$ & 3.92 & .861 & .608 \\
\hline $\begin{array}{l}\text { 6. The managerial level in the organization is task and duty } \\
\text { specified. }\end{array}$ & 3.85 & .788 & .616 \\
\hline $\begin{array}{l}\text { 7. Information Technologies specialists don't find any difficulty } \\
\text { in dealing with the ERP System in the organization. }\end{array}$ & 3.89 & 1.08 & .605 \\
\hline \multicolumn{4}{|l|}{ Group 2} \\
\hline $\begin{array}{l}\text { 8. ERP System support and success the decision making } \\
\text { processes. }\end{array}$ & 4.05 & .858 & .847 \\
\hline 9. ERP System improved the operations and services. & 4.10 & .840 & .812 \\
\hline 10. ERP System can support and achieve our objectives. & 4.14 & .847 & .805 \\
\hline Total & 3.87 & 0.523 & \\
\hline
\end{tabular}

As it is seen from the table (6) the total Mean for this field is (3.87) with Standard deviation $(0.524)$.

In group (1) the highest Mean for question (3)" The procedures are clear for managers" which is (4.01) with Standard deviation (0.811). The lowest Mean for question (5)" The daily operations and plans are understood by the employees" which is (3.85) and Standard deviation (0.788). In group (2) all questions Mean is above (4.0) and the Standard deviation for questions (8-9-10) is following consecutive values $(0.858-0.840-0.847)$. 
International Journal of Managing Information Technology (IJMIT) Vol.7, No.1, February 2015

The table (6) shows that all values in group (1) for Mean is greater than (3.8) which mean that the sample agree with the clarity of the objectives, operation and services on the organization. Moreover, agree with the important of using ERP System for achieving objectives and giving good services for citizens. The other side for testing this hypothesis is the answer for this question:

Is there a correlation between Organization objectives and services and ERP System?

To answer this question the researcher use Pearson Correlation test. The table (7) explains there is a positive correlation between group (1) and group (2). The value for Pearson Correlation is (0.695) this Correlation is significant at the 0.01 level (1-tailed).

Table 7: Correlation between Organization objectives and services and ERP System

\begin{tabular}{|l|l|l|l|}
\hline & & Group1 & Group2 \\
\hline Group1 & $\begin{array}{l}\text { Pearson } \\
\text { Correlation }\end{array}$ & 1 & $.695(* *)$ \\
\hline & Sig. (1-tailed) &. & .000 \\
\hline & $\mathrm{N}$ & 400 & 400 \\
\hline Group2 & $\begin{array}{l}\text { Pearson } \\
\text { Correlation }\end{array}$ & $.695(* *)$ & 1 \\
\hline & Sig. (1-tailed) & .000 &. \\
\hline & N & 400 & 400 \\
\hline \multicolumn{2}{|l|}{ Correlation is significant at the 0.01 level (1-tailed). }
\end{tabular}

The results indicate that there is a significant correlation of Organization objectives and services on ERP System implementation.

There is availability of the Organization objectives and services for Success ERP System implementation in GAM. So the Hypothesis (H1:a) - "There is significant correlation between organization objectives and services and ERP system implementation" is acceptable .

(H1:b) -There is significant correlation between organizational culture and ERP system Implementation. 
International Journal of Managing Information Technology (IJMIT) Vol.7, No.1, February 2015

Table 8: Descriptive Statistics and loading for the Organizational Culture

\begin{tabular}{|c|c|c|c|}
\hline Section & Mean & Std & Loading \\
\hline \multicolumn{4}{|l|}{ Group 3} \\
\hline $\begin{array}{l}\text { 11. There is a helpful relation ship between the employees in the } \\
\text { organization. }\end{array}$ & 3.76 & .781 & .767 \\
\hline $\begin{array}{l}\text { 12. There is a good teamwork between employees in the } \\
\text { organization. }\end{array}$ & 3.97 & .841 & .640 \\
\hline $\begin{array}{l}\text { 13.Exchange of experience and information is done between } \\
\text { employees and managers. }\end{array}$ & 3.82 & .881 & .859 \\
\hline $\begin{array}{l}\text { 14.Exchanging of information between employees is done easily } \\
\text { during work. }\end{array}$ & 3.95 & 1.09 & .834 \\
\hline $\begin{array}{l}\text { 15.All the Systems in the organization are integrated \& facilitate } \\
\text { the communication between the organization's departments \& } \\
\text { the outside. }\end{array}$ & 3.99 & .924 & .831 \\
\hline $\begin{array}{l}\text { 16. The control standards and Performance evaluation on the } \\
\text { employees in the organization are fair }\end{array}$ & 3.84 & .677 & .856 \\
\hline 17.The working atmosphere in the organization is positive. & 3.93 & 1.06 & .828 \\
\hline \multicolumn{4}{|l|}{ Group 4} \\
\hline $\begin{array}{l}\text { 18.ERP System will enhance the level of the organizational } \\
\text { learning. }\end{array}$ & 4.08 & .880 & .808 \\
\hline $\begin{array}{l}\text { 19.ERP System has positive effects on groups s values regarding } \\
\text { leaming \& innovation issues. }\end{array}$ & 4.05 & .877 & .916 \\
\hline $\begin{array}{l}\text { 20. ERP System will contribute in enhancing the exchange of } \\
\text { ideas \& experiences between the employees in the organization. }\end{array}$ & 4.08 & .873 & .877 \\
\hline Total & 3.94 & 0.538 & \\
\hline
\end{tabular}

Table (8) shows the total Mean for Organizational Culture factor is (3.94) and Standard deviation (0.538). In this table there are two groups; group (3) which includes the questions from (11 to 17) for Organizational Culture. Group (4) includes questions from (18 to 20) for ERP System.

In group (3) the highest Mean for section number (15)" All the Systems in the organization are integrated" which is (3.99) with Standard deviation (0.924). About the item number (17) "There is a good teamwork between employees in the organization" the Mean is (3.93). The lowest Standard deviation is ( 0.677) for section 16. The table shows that all Mean values for group (3) is greater than (3.7) which means that the Significance level for sample in agree level. So the Organizational Culture is suitable for implementing ERP System in GAM. In group (4) the highest Mean is (4.08) for item number (20). But this value is comparable with the arithmetic Mean for the other items of the group(4) which are for item (18) the mean is (4.08) and item number (19) the Mean is (4.05) with Standard deviation(0.877) .

Table (9) shows the correlation between Organizational Culture and ERP System. This explains there is a positive correlation between group (3) and group (4). The value for Pearson Correlation was (0.727) this Correlation is significant at the 0.01 level (1-tailed). 
International Journal of Managing Information Technology (IJMIT) Vol.7, No.1, February 2015

Table 9: Correlation between organizational culture and ERP System

\begin{tabular}{|l|l|l|l|}
\hline & & Group 3 & Group 4 \\
\hline Group 3 & Pearson Correlation & 1 & $.727(* *)$ \\
\hline & Sig. (2-tailed) &. & .000 \\
\hline & N & 400 & 400 \\
\hline Group 4 & Pearson Correlation & $.727(* *)$ & 1 \\
\hline & Sig. (2-tailed) & .000 &. \\
\hline & N & 400 & 400 \\
\hline
\end{tabular}

***orrelation is significant at the 0.01 level (2-tailed).

We can deduce from the table (8) that the appropriate organizational culture for the success implementing for ERP. In addition to that table (9) presents the strong positive Correlation between organizational culture and ERP System.

Finally the Hypothesis (H1: b) "There is significant correlation between organizational culture and ERP system Implementation" is acceptable.

(H1:c) - There is significant correlation between Business process and ERP system implementation.

Table 10: Descriptive Statistics and loading for the Business Process

\begin{tabular}{|c|c|c|c|}
\hline Section & Mean & Std & Loading \\
\hline \multicolumn{4}{|l|}{ Group 5} \\
\hline $\begin{array}{l}\text { 21. The duties \& operations in all departments are specific \& } \\
\text { clear }\end{array}$ & 3.99 & .972 & .662 \\
\hline $\begin{array}{l}\text { 22.There is an integration between all operations in the } \\
\text { Municipality. }\end{array}$ & 4.01 & .900 & .684 \\
\hline 23.The time is specific \& suitable for each operation. & 3.91 & .980 & .717 \\
\hline $\begin{array}{l}\text { 24. There are clear channels of communication in our } \\
\text { organization. }\end{array}$ & 3.95 & .928 & .752 \\
\hline $\begin{array}{l}25 . \text { The Technological systems in the organization are all } \\
\text { integrated }\end{array}$ & 3.84 & .974 & .738 \\
\hline $\begin{array}{l}\text { 26. The work done by the Municipality of Amman is integrated } \\
\text { with the rest of the governmental institutions' work. }\end{array}$ & 4.01 & .856 & 677 \\
\hline $\begin{array}{l}\text { 27. There is an easy sharing of information between the } \\
\text { employees and the citizens. }\end{array}$ & 3.94 & .898 & .654 \\
\hline \multicolumn{4}{|l|}{ Group 6} \\
\hline $\begin{array}{l}\text { 28. The new (ERP) system will minimize the time for the } \\
\text { operation. }\end{array}$ & 3.92 & .834 & .712 \\
\hline $\begin{array}{l}\text { 29. The new (ERP) system will facilitate information sharing \& } \\
\text { exchanging experiences between the employees. }\end{array}$ & 3.98 & .881 & .894 \\
\hline $\begin{array}{l}\text { 30. The new (ERP) system can improve the services provided } \\
\text { for the citizens }\end{array}$ & 4.01 & .845 & .819 \\
\hline Total & 3.96 & 0.506 & \\
\hline
\end{tabular}

Similar results between table (10) and tables (6) and (8). The total Mean for Business process factor is (3.96) and Standard deviation (0.506). In this table there are two groups; group (5) which includes the sections from (21 to 27) for Business process. Group (6) includes sections from (28to 30) for ERP System. 
International Journal of Managing Information Technology (IJMIT) Vol.7, No.1, February 2015

In group (5) the highest Mean in this factor is (4.01) for two sections (26)"The work done by the GAM is integrated with the rest of the governmental institutions' work" and number (22)"There is integration between all operations in the Municipality", but the Standard deviation for section (26) is lower than section (22) is (0.856).

Table (10) shows that all Mean values for group (5) is more than (3.8) which means that the Significance level for sample in agree level. So the Business Process is suitable for implementing ERP System in GAM. In group (6) the highest Mean is (4.01) for item number (30) with Standard deviation (.845).

The other items of the group (6) which are for item (28) the Mean is (3.92) and item number (29) the Mean is (3.92). All values for Mean in group (6) is in agree Significance level.

Table (11) presents the Pearson correlation between Business Process and ERP System is (0.681) this explains there is a positive correlation between group (5) and group (6) this Correlation is significant at the 0.01 level (1-tailed).

We can deduce from the table (10) that Business Process compatible for the success implementing for ERP. In addition to that table (11) presents the strong positive Correlation between Business Process and ERP System. So the Hypothesis (H1: c) "There is significant correlation between Business Process and ERP system Implementation" is acceptable.

Table 11: Correlation between Business Process and ERP System

\begin{tabular}{|l|l|l|l|}
\hline & & Group 5 & Group 6 \\
\hline Group 5 & Pearson Correlation & 1 & $.681(* *)$ \\
\hline & Sig. (2-tailed) &. & .000 \\
\hline & $\mathrm{N}$ & 400 & 400 \\
\hline Group 6 & Pearson Correlation & $.681(* *)$ & 1 \\
\hline & Sig. (2-tailed) & .000 &. \\
\hline & $\mathrm{N}$ & 400 & 400 \\
\hline
\end{tabular}

** Correlation is significant at the 0.01 level (2-tailed).

From all of results above the researcher concludes that (H1): There Is a Significant correlation between The Organizational Factors and ERP system Implementation in GAM is acceptable.

\subsection{Second hypothesis}

(H2): There Is a Significant correlation between Technological Factors and ERP system Implementation success in GAM.

To examining this Hypothesis the researcher first: calculates Means, Standard deviation and Factor analysis ( loading ) for each item for the Organizational Factors in GAM. Second calculates Pearson Correlation between group (7) which includes items from (31 to 38) for the Technological infrastructure and Network communication technology, and group (8) which includes the items (39 and 40) for ERP system. Tables from (12) to (13) show the results. 
International Journal of Managing Information Technology (IJMIT) Vol.7, No.1, February 2015

Table12: Descriptive Statistics and loading for the Technological infrastructure and Network communication technology

\begin{tabular}{|c|c|c|c|}
\hline Section & Mean & Std & Loading \\
\hline \multicolumn{4}{|l|}{ Group 7} \\
\hline 31. In the organization's structure there is an IT department. & 4.08 & .782 & .782 \\
\hline $\begin{array}{l}\text { 32. The employees in the IT department are experienced with } \\
\text { efficient. }\end{array}$ & 4.10 & .783 & .897 \\
\hline 33. There is a maintenance staffin the IT department & 4.19 & .726 & .875 \\
\hline 34. The role for communication in the organization is clear. & 4.06 & .910 & .819 \\
\hline $\begin{array}{l}\text { 35. The LAN in the organization increases the efficiency of } \\
\text { exchanging information between the employees. }\end{array}$ & 4.18 & .820 & .802 \\
\hline Total & 4.107 & 0.502 & \\
\hline $\begin{array}{l}\text { 36. The Municipality website facilitates the exchange of } \\
\text { information with the citizens. }\end{array}$ & 4.16 & .805 & .802 \\
\hline $\begin{array}{l}\text { 37. The citizens have access to their needed information through } \\
\text { the Municipality website }\end{array}$ & 4.18 & .810 & .831 \\
\hline $\begin{array}{l}\text { 38. The citizens can know the objectives and the Municipality } \\
\text { services through the website. }\end{array}$ & 4.20 & .775 & .865 \\
\hline Total & 4.18 & 0.505 & \\
\hline \multicolumn{4}{|l|}{ Group 8} \\
\hline $\begin{array}{l}\text { 39. The ERP system will increase the capacity of } \\
\text { communication with the citizens }\end{array}$ & 4.10 & .828 & .854 \\
\hline $\begin{array}{l}\text { 40. The ERP system can help in facilitating the exchange of } \\
\text { information via communication channels. }\end{array}$ & 4.24 & .827 & .743 \\
\hline Total & 4.14 & 0.503 & \\
\hline
\end{tabular}

Table (12) shows the total Mean for Technological infrastructure is (4.107) and Standard deviation (0.502) and the total Mean for Network and communication technology (4.18) with Standard deviation (0.505). This values for Mean indicate the Significance level for these filed is agree.

To show the correlation between Technological Factors and ERP System table (13) explains there is a positive correlation between group (7) and group (8). The value for Pearson Correlation was (0.631) this Correlation is significant at the 0.01 level (1-tailed).

Table 13: Correlation between Technological Factors and ERP System

\begin{tabular}{|l|l|l|l|}
\hline & & Group 7 & Group 8 \\
\hline Group 7 & Pearson Correlation & 1 & $.631(* *)$ \\
\hline & Sig. (1-tailed) &. & .000 \\
\hline & N & 400 & 400 \\
\hline Group 8 & Pearson Correlation & $.631(* *)$ & 1 \\
\hline & Sig. (1-tailed) & .000 &. \\
\hline & N & 400 & 400 \\
\hline
\end{tabular}

**Correlation is significant at the 0.01 level (1-tailed).

The results indicate that there is a significant correlation between Technological Factors and ERP System implementation. And there is availability of the Technological Factors for Success ERP System implementation in GAM. 
International Journal of Managing Information Technology (IJMIT) Vol.7, No.1, February 2015

So the hypothesis (H2) "There is significant correlation between Technological Factors and ERP system implementation" is acceptable.

\subsection{Summary of Hypotheses}

Table (14) shows the results of testing the hypotheses of the research.

Table 14: Summary of Results

\begin{tabular}{|l|l|l|}
\hline No & Hypotheses & Results \\
\hline H1 & $\begin{array}{l}\text { There Is a Significant Impact of The Organizational } \\
\text { Factors on ERP system Implementation in GAM }\end{array}$ & Accepted \\
\hline H2 & $\begin{array}{l}\text { There Is a Significant Impact of The Technological } \\
\text { Factors on ERP system Implementation success in GAM. }\end{array}$ & Accepted \\
\hline
\end{tabular}

\section{CONCLUSIONS}

This work studied the relationship between Organizational and Technological Factors with ERP system at the pre- implementation stage in GAM, The results showed that there is a significant impact of Organizational Factors, and Technological Factors on ERP System Implementation. We can deduce from all of the above that there is a correlation between Organizational Factors and ERP System Implementation, and that the Organizational Factors are available at GAM to guarantee the Success of ERP Implementation.

Furthermore, the results shows that GAM have advanced technological infrastructure, and appropriate to the success of ERP System Implementation. The same results shows that GAM have advanced Network and communication technology too. We can conclude that the Technological Factors are available at GAM to guarantee the Success of ERP Implementation

\section{REFERENCES}

[1] H. Barki, S. Oktamis, and A. Pinsonneault, (2005), "Dimensions of ERP Implementations and their impact on ERP project outcomes," Journal of Information Technology Management, vol. 16, no. 1, pp. 1-9.

[2] M. Alves, and S. Matos, (2011), "An investigation into the Use of ERP Systems in the Public Sector," Journal of the Enterprise Resource Planning Studies Volume article ID, vol. 950191.

[3] M. T. Morden, (2012), Principles of strategic management: Ashgate Publishing, Ltd..

[4] J. Zhang, Z. Wu, P. Feng and Y. Dingwen, (2006), "A Methodology and Conceptual Framework for Flow-Manufacturing-Oriented ERP Systems", Enterprise Distributed Object Computing Conference Workshops, EDOCW'06. 10th IEEE International, pp. 17-17.

[5] M. Garg, (2010), "Impact of Enterprise Resource Planning on Organizational Productivity in an Information Technology Organization," ProQuest LLC.

[6] W. A. Carson III, and B. A. Adviser-Bailey, (2005), "Successful implementation of enterprise resource planning software: A Delphi study", Dissertation, Capella University.

[7] Almashaqba, (2009), "Critical Factors Affecting An Enterprise Resource Planning Systems (ERPs) Implementation Success In Jordan," Thesis, The Arab Academy for Banking and Financial Sciences.

[8] S. I. H. Shah, R. H. Bokhari, S. Hassan Shah, M. H. Shah,and M. Ali, (2011), "Socio-technical factors affecting ERP implementation success in Pakistan: an empirical study," Australian Journal of Basic and Applied Sciences, vol. 5, no. 3, pp. 742-749.

[9] W. H. DeLone, and E. R. McLean, (1992), "Information systems success: the quest for the dependent variable," Information systems research, vol. 3, no. 1, pp. 60-95. 
International Journal of Managing Information Technology (IJMIT) Vol.7, No.1, February 2015

[10] Y. Yusuf, A. Gunasekaran, and M. S. Abthorpe, (2004), "Enterprise information systems project implementation: A case study of ERP in Rolls-Royce," International Journal of Production Economics, vol. 87, no. 3, pp. 251-266.

[11] M. Bradford, and J. Florin, (2003), "Examining the role of innovation diffusion factors on the implementation success of enterprise resource planning systems," International journal of accounting information systems, vol. 4, no. 3, pp. 205-225.

[12] P. Bingi, M. K. Sharma, and J. K. Godla, (1999), "Critical issues affecting an ERP implementation," IS Management, vol. 16, no. 3, pp. 7-14.

[13] E. J. Umble, and M. M. Umble, (2002), "Avoiding ERP implementation failure," Industrial Management, vol. 44, no. 1, pp. 25-33.

[14] J. Motwani, D. Mirchandani, M. Madan and A. Gunasekaran, (2002), "Successful implementation of ERP projects: evidence from two case studies," International Journal of Production Economics, vol. 75, no. 1 , pp. 83-96.

[15] L. Zhang, M. K. Lee, Z. Zhang, and P. Banerjee, (2003), "Critical success factors of enterprise resource planning systems implementation success in China.", System Sciences, Proceedings of the 36th Annual Hawaii International Conference on. IEEE, p. 10 pp.

[16] S. M. Imroz, L. R. Pietron, D. A. Haworth and K. W. Ward, (2010), “Application of Q-methodology in Critical Success Factors of Information Security Risk Management," nternational Handbook of Academic Research and Teaching, pp. 146, 2010.

[17] U. Sekaran, (1992), "Research Methods of Business-A Skill-Building Approach", John Wiley \& Sons.

\section{Authors}

Suha Afaneh, is an assistant professor in Isra University (Jordan). She received her Ph.D. degree from Amman Arab University (Jordan) in 2010. Her research interests include artificial intelligence and simulation, information retrieval, software engineering, and data base management systems.

Issam Hamad Al Hadid, is an assistant professor in Isra University (Jordan). He received his $\mathrm{Ph}$.D. degree from University of Banking and Financial Sciences (Jordan) in 2010. His field research lies in design and architecture of Self-Healing, also his research interests include artificial intelligence and expert system, knowledge base systems, simulation, information retrieval, and software engineering.

Heba AlMalahmeh, is an assistant professor. She received her Ph.D. degree from Banking and Financial Sciences (Jordan) in 2012. Her research interests include information retrieval, system analysis, management information systems, and data base management systems.
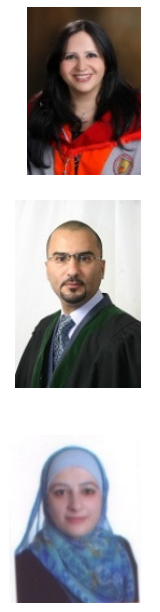